\title{
PPAR ligands decrease human airway smooth muscle cell migration and extracellular matrix synthesis
}

\author{
Jancy Stephen*, Chris Delvecchio\#, Naomi Spitale*, Amanda Giesler*, \\ Katherine Radford*, Pat Bilan*, P. Gerard Cox*, John P. Capone ${ }^{\#}$ \\ and Parameswaran Nair*
}

ABSTRACT: Airway smooth muscle cells produce extracellular matrix proteins, which in turn can promote smooth muscle survival, proliferation and migration. Currently available therapies have little effect on airway smooth muscle matrix production and migration. Peroxisome proliferatoractivated receptor (PPAR) ligands are reported to decrease migration and matrix production in various cell lines. In this study, we examined the effect of PPAR ligands on human airway smooth muscle (HASM) matrix production and migration.

PPAR expression was examined by RT-PCR and Western blotting. Endogenous PPAR activity was examined by transfecting cells with a PPAR response element-luciferase reporter plasmid.

We observed that HASM cells express PPAR $\alpha, \beta$ and $\gamma$. A six-fold induction of luciferase activity was observed by stimulating cells with a pan-agonist, indicating endogenous PPAR activity. The PPAR ligands ciglitazone, 15-deoxy- $\Delta 12,14-$ prostaglandin $\mathrm{J}_{2}$ and WY-14643 decreased migration towards platelet-derived growth factor receptor. This was not mediated by inhibiting Akt phosphorylation or promoting PTEN activity, but partly through cyclooxygenase-2 induction and prostaglandin $E_{2}$ production that increased cyclic AMP levels in the cells. All three ligands also caused an inhibition of collagen and fibronectin secretion by cultured smooth muscle cells.

We conclude that PPAR ligands decrease HASM migration and matrix production and are, therefore, potentially useful for modulating airway remodelling.

KEYWORDS: Airway smooth muscle migration, asthma, extracellular matrix, peroxisome proliferator-activated receptor, prostaglandin $\mathrm{E}_{2}$

$\mathbf{T}$ wo conspicuous features of the airway walls of patients with severe asthma are an increased quantity of smooth muscle cells and extracellular matrix (ECM) components [1]. The increased smooth muscle mass is more likely to be due to increased number (hyperplasia) than size of the cells (hypertrophy) [2,3]. One of the mechanisms of smooth muscle accumulation in the remodelled airway may be by migration from deeper smooth muscle bundles in the submucosa $[4,5]$, which, in turn, is partly regulated by ECM proteins such as collagen and fibronectin [6]. Both these structural changes, which contribute to airflow limitation in asthma [7], are not effectively reversed by currently available asthma medications. Thus, it would be attractive to identify mechanisms or strategies that would inhibit both smooth muscle migration and matrix production.

Peroxisome proliferator-activated receptors (PPARs) are a family of hormone receptors that belong to the steroid receptor superfamily [8]. The PPAR $\alpha$ and $\gamma$ isoforms are reported to be expressed on airway smooth muscle cells [9, 10], and their activation by ligands such as the thiazolidinedione rosiglitazone have anti-inflammatory properties that are superior to corticosteroids [11]. PPAR ligands can decrease human vascular smooth muscle migration [12] and matrix production by renal mesangial cells [13]. Proposed mechanisms include: direct transcriptional activation or suppression of target genes [14]; antagonism of other signal-dependent transcription factors, such as nuclear factor- $\mathrm{kB}$, activator protein-1 or CAAT/ enhancer binding protein; activation of signalling pathways that involve phosphoinositide 3-kinase (PI3K), Src or mitogen-activated protein kinase [15]; inhibiting signals such as PTEN (phosphatase and tensin homologue) by modulating activation of cyclooxygenase (COX) and increasing intracellular cyclic AMP (cAMP) [16]; or by decreasing or interrupting transforming growth factor (TGF)- $\beta 1$
AFFILIATIONS

*Firestone Institute for Respiratory Health, St Joseph's Healthcare, Dept of Medicine, McMaster University, and

"Dept of Biochemistry and Biomedical Sciences, McMaster University, Hamilton, ON, Canada.

CORRESPONDENCE

P. Nair

Firestone Institute for Respiratory Health

St Joseph's Healthcare

Hamilton

ON

L8N 4A6

Canada

E-mail: parames@mcmaster.ca

Received:

Sept 122009

Accepted after revision: April 172012

First published online:

May 312012

European Respiratory Journal Print ISSN 0903-1936 Online ISSN 1399-3003 
level [17] or signalling [18]. Activation of other nuclear hormone receptors, such as the liver $\mathrm{X}$ receptor, has been demonstrated to decrease human airway smooth muscle (HASM) migration towards chemotactic stimuli $[19,20]$.

In this study, we investigated: the expression of PPAR isoforms on HASM cells; the effects of their ligands on smooth muscle migration, and production of collagen and fibronectin; and some mechanisms of these effects. Specifically, we examined the role of Akt, Src, PTEN and COX signalling to offer some explanations for the phenomena that we set out to explore. We used four different agonists (WY-14643 for the PPAR $\alpha$, GW501516 for the PPAR $\beta$, and ciglitazone/troglitazone and 15-deoxy- $\Delta 12,14$-prostaglandin $\mathrm{J}_{2}\left(15 \mathrm{~d}-\mathrm{PGJ}_{2}\right)$ for PPAR $\gamma$ ) and three antagonists (MK866 against PPAR $\alpha$, sulindac against PPAR $\beta$ and GW9662 against PPAR $\gamma$ ) to study the role of specific PPAR isoforms. We demonstrate that PPAR ligands, similarly to other nuclear hormone receptor ligands, inhibit the migration of HASM cells towards platelet-derived growth factor (PDGF) and attenuate collagen secretion from HASM cells.

\section{METHODS}

\section{Airway smooth muscle culture}

Portions of human lungs that were resected at St Joseph's Healthcare (Hamilton, ON, Canada) were obtained from 16 patients (table 1) undergoing surgery for lung cancer with their informed consent and approval from the hospital Research Ethics Board. Smooth muscle tissue was isolated from macroscopically disease-free areas of human bronchi. HASM cells were grown to confluence as described previously $[4,6]$. The cells were passaged between two and five times and used for the experiments.

\section{Detection of PPAR transcripts}

Total RNA was isolated from HASM cells and $1 \mu \mathrm{g}$ was reverse-transcribed using Quantitect Reverse Transcription according to the manufacturer's instructions (QIAGEN, Toronto, ON, Canada). PPAR isoforms were then amplified using gene-specific primers in an Applied Biosystems 7900HT machine (Applied Biosystems, Carlsbad, CA, USA). Briefly, reactions contained $12.5 \mu \mathrm{L}$ SYBR Green PCR supermix (Invitrogen, Burlington, ON, Canada), $10.5 \mu \mathrm{L} \mathrm{H}_{2} \mathrm{O}, 1 \mu \mathrm{L}$ primer sets $(10 \mu \mathrm{M}$ each) and $1 \mu \mathrm{L}$ cDNA. PCR amplification was carried out for 28 cycles with the following parameters:

\begin{tabular}{ll} 
TABLE 1 & $\begin{array}{l}\text { Clinical characteristics of subjects who donated } \\
\text { airways }\end{array}$ \\
Subjects & 16 \\
Males & 12 \\
Age yrs & $52 \pm 22$ \\
Smokers & 11 \\
Atopy & 6 \\
FEV $\mathbf{L}$ & $1.9 \pm 1.5$ \\
FEV $\mathbf{1} \%$ pred & $68 \pm 23$ \\
FEV $\mathbf{1}$ : $\mathbf{C} \%$ & $64 \pm 33$ \\
\hline
\end{tabular}

Data are presented as $n$ or mean $\pm \mathrm{SD}$. FEV1: forced expiratory volume in $1 \mathrm{~s} ; \%$ pred: \% predicted; VC: vital capacity. denaturation at $95^{\circ} \mathrm{C}$ for $15 \mathrm{~min} ; 30$ cycles at $95^{\circ} \mathrm{C}$ for $30 \mathrm{~s}$; and $60^{\circ} \mathrm{C}$ for $1 \mathrm{~min}$. Products were separated on $2 \%$ agarose gels, stained with SYBR Green and imaged on a Typhoon 9200 Variable Mode Imager (Amersham Biosciences, Baie D’Urfe, QC, Canada).

The primer sequences were as follows (all presented as $5^{\prime}-3^{\prime}$ ). PPAR $\alpha$ : forward primer, AGCCTAAGGAAACCGTTCTG; reverse primer ACGATCTCCACAGCAAATGA. PPAR $\beta / \delta$ : forward primer, TCACACAACGCTATCCGTTT; reverse primer, GGCATTGTAGATGTGCTTGG. PPAR $\gamma$ : forward primer, ACCAGCTGAATCCAGAGTCC; reverse primer, CGAATGGTGATTTGTCTGTTG.

\section{PPAR transfections and reporter gene assay}

HASM cells were transfected with $0.4 \mu \mathrm{g}$ of a PPAR response element (PPRE)-luciferase reporter gene in six-well dishes at $\sim 75 \%$ confluence using Effectene (QIAGEN) according to the manufacturer's instructions. Briefly, per well, $0.4 \mu \mathrm{g}$ of a PPREluciferase reporter plasmid, which contains three copies of the murine PPRE from acyl-coenzyme A oxidase, was incubated for $5 \mathrm{~min}$ at room temperature with $95 \mu \mathrm{L}$ enhancer reagent and 3.2 $\mu \mathrm{L}$ enhancer. $10 \mu \mathrm{L}$ Effectene was then added for an additional $10 \mathrm{~min}$ followed by $600 \mu \mathrm{L}$ RPMI medium supplemented with $10 \%$ fetal bovine serum (FBS) and incubated overnight. Following transfection, the cells were incubated overnight in Dulbecco's modified Eagle's medium lacking phenol red supplemented with 10\% charcoal-stripped FBS, 1\% L-glutamine and $1 \%$ penicillin/streptomycin with $1 \mu \mathrm{M}$ panagonist (Full 2; obtained from J. Berger, Merck Frosst, Montreal, QC, Canada) alone or in combination with PPAR $\alpha$ antagonist $(\mathrm{MK} 866,10 \mu \mathrm{M}), \operatorname{PPAR} \beta / \delta$ antagonist (sulindac, $10 \mu \mathrm{M}$ ), PPAR $\gamma$ antagonist (GW9662, $10 \mu \mathrm{M})$ or all three together for an additional $48 \mathrm{~h}$ (fresh ligand was added after $24 \mathrm{~h}$ ). Control cells received an equivalent amount of vehicle. Luciferase activity was assayed as described previously [19].

\section{Migration assay}

Migration experiments were performed using $6.5-\mathrm{mm}$ Transwell culture plates with $8.0-\mu$ m pores that were collagen I-coated with a polycarbonate membrane separating the inner and outer chambers (Fisher Scientific Limited, Nepean, ON, Canada), as previously described [4, 6]. Assays were performed in duplicate using tissues from six different lung specimens. Migration was studied by adding PDGF-BB (20 ng. $\mathrm{mL}^{-1}$; Invitrogen) to the outer well. The effects of PPAR ligands were studied by treating the cells with various concentrations $\left(0.1-100 \mathrm{ng} \cdot \mathrm{mL}^{-1}\right)$ of the ligands for $30 \mathrm{~min}$ prior to adding PDGF. The viability of cells treated with various agonists was checked by confirming that the cell numbers under the various conditions were between $93 \%$ and $151 \%$ of the untreated controls using an MTT assay.

\section{ELISA}

Collagen and fibronectin

HASM cells were plated at $10^{4}$ cells per well in 96-well plates. After 4 days, they were growth-arrested for $48 \mathrm{~h}$ with $0.3 \%$ bovine serum albumin (BSA) in RPMI then treated with various concentrations of the PPAR ligands for $48 \mathrm{~h}$. ECM was harvested from the plates by incubating with $0.02 \mathrm{M}$ ammonium hydroxide for $5 \mathrm{~min}$ at room temperature. The plates were 
a)

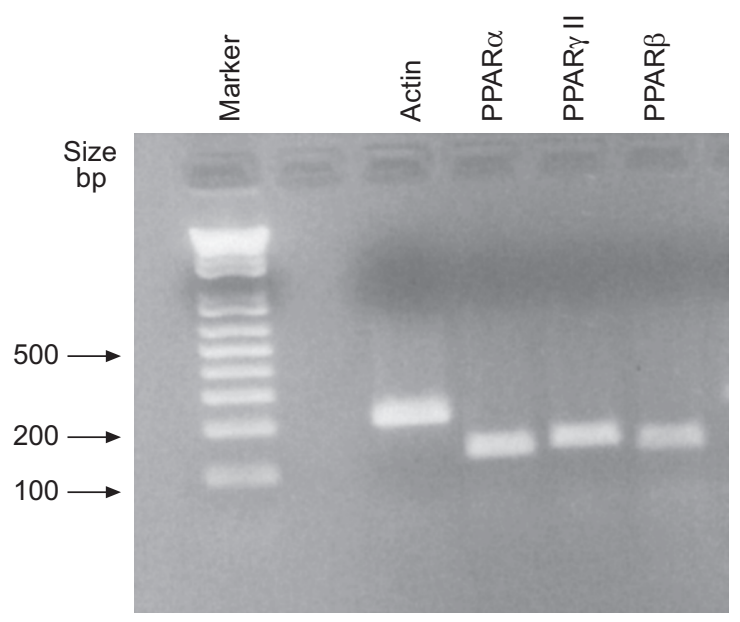

b)

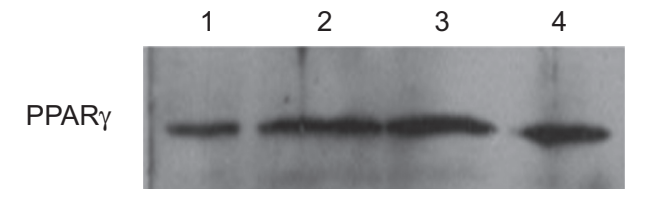

PPAR $\alpha$

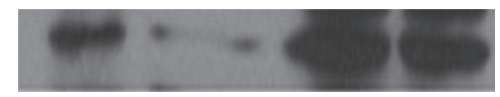

PPAR $\beta$

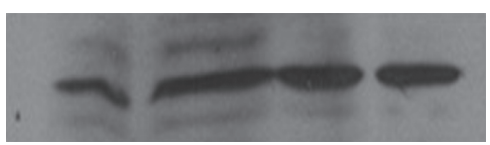

c)

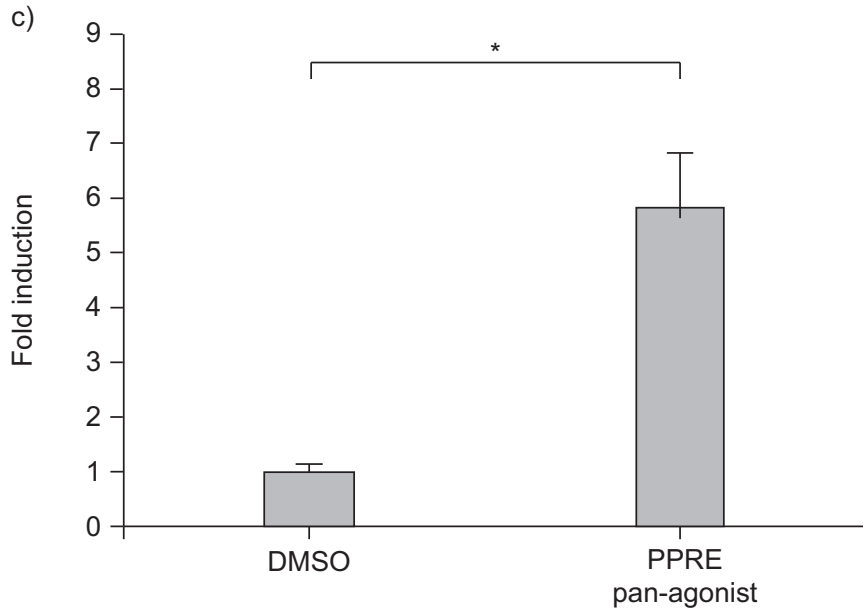

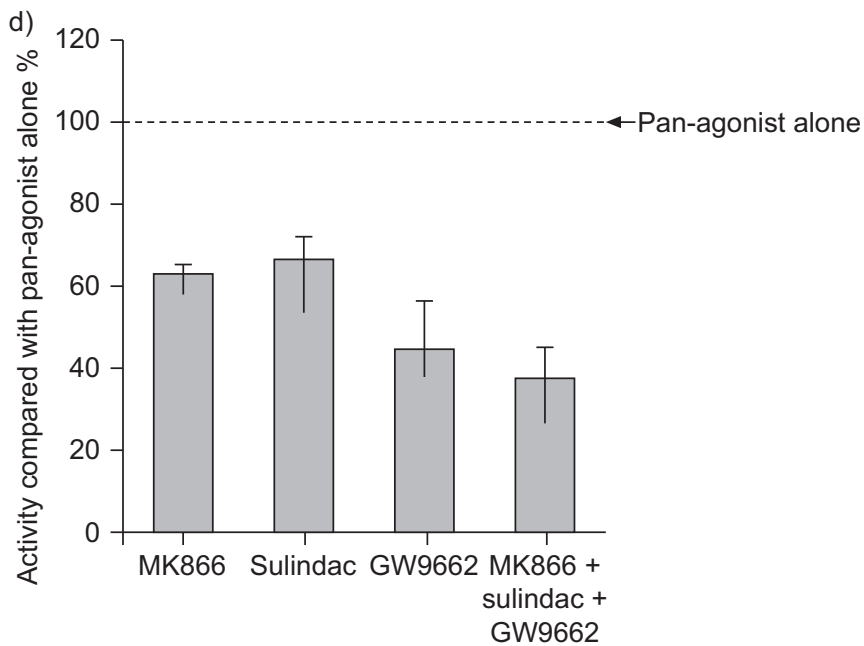

FIGURE 1. a) A representative gel of PCR products demonstrating expression of peroxisome proliferator-activated receptor (PPAR) $\alpha, \gamma$ and $\beta$ expression on cultured human airway smooth muscle (HASM) cells. b) Western blotting demonstrating that HASM cells from four different donors express PPAR $\alpha, \beta$ and $\gamma$. c) HASM cells transfected with a PPAR response element (PPRE)-luciferase reporter gene demonstrates endogenous PPAR activity when stimulated with a pan-PPAR agonist (six-fold induction compared with control). DMSO: dimethylsulfoxide. *: $p<0.05$. d) PPAR antagonists repress PPRE reporter genes in the presence of a PPAR pan-agonist. HASM cells were transfected with a PPRE-luciferase reporter gene and treated with pan-agonist $(1 \mu \mathrm{M})$ alone or in combination with PPAR $\alpha$ antagonist (MK866, $10 \mu \mathrm{M})$, PPAR $\beta$ antagonist (sulindac, $10 \mu \mathrm{M}$ ), PPAR $\gamma$ antagonist (GW9662, $10 \mu \mathrm{M}$ ) or all three together, as indicated. Cells were incubated for $24 \mathrm{~h}$ and luciferase activity was measured. Data are presented as the mean \pm SD of three experiments, with pan-agonist alone taken as $100 \%$. Compared with the pan-agonist alone, all of the three specific antagonists and the three antagonists in combination significantly reduced PPRE-luciferase gene expression ( $p<0.05$ for all).

stored at $-70^{\circ} \mathrm{C}$ until the assays were run. Primary antibodies to fibronectin (1:5,000 dilution; BD Biosciences, Oakville, ON, Canda) and collagen (1:2,000 dilution, Sigma, Oakville, ON, Canada) were added to the plates and then incubated with secondary antibody (goat anti-mouse) in $200 \mu \mathrm{L}$ blocking buffer. The colour was developed with $100 \mu \mathrm{L}$ p-nitrophenyl phosphate solution (Sigma) and the absorbance was read at $405 \mathrm{~nm}$.

\section{Prostaglandin $E_{2}$}

Prostaglandin (PG) $\mathrm{E}_{2}$ levels in smooth muscle culture supernatants were measured by a sensitive enzyme immunoassay according to the manufacturer's instructions (Assay Designs, Ann Arbor, MI, USA). The limit of detection for $\mathrm{PGE}_{2}$ was $13.4 \mathrm{pg} \cdot \mathrm{mL}^{-1}$.

Cyclic AMP

HASM cells were grown to confluence, growth-arrested for $24 \mathrm{~h}$, treated with the various agonists for the same duration as the migration assay ( $5 \mathrm{~h}$ ) and cAMP was assayed in the supernatant using a sensitive immunoassay according to the manufacturer's instruction (R\&D Systems Inc, Minneapolis, MN, USA).

\section{Western blotting}

HASM cells were cultured in six-well plates and grown to $\sim 90 \%$ confluence. The cells were then serum-starved in $0.2 \%$ BSA in RPMI for $24 \mathrm{~h}$. The cells were then pre-treated with the PPAR agonists for $1 \mathrm{~h}$ followed by treatment with PDGF $\left(20 \mathrm{ng} \cdot \mathrm{mL}^{-1}\right)$ for the indicated times. Cells were then lysed in $0.1 \%$ Triton $\mathrm{X}-100$ detergent containing protease and phosphatase inhibitors, and extracts $(20 \mu \mathrm{g})$ were separated by sodium dodecylsulfate-polyacrylamide gel electrophoresis and blotted onto nitrocellulose. Membranes were blocked with 5\% milk powder in Tris-buffered saline-Tween-20 (TBS-T) for $1 \mathrm{~h}$ and were first probed with antibodies for phosphoSrcY416 $(1: 1,000)$, phosphoAktS473 (1:1,000), PTEN $(1: 1,000)$ (Cell Signaling, 

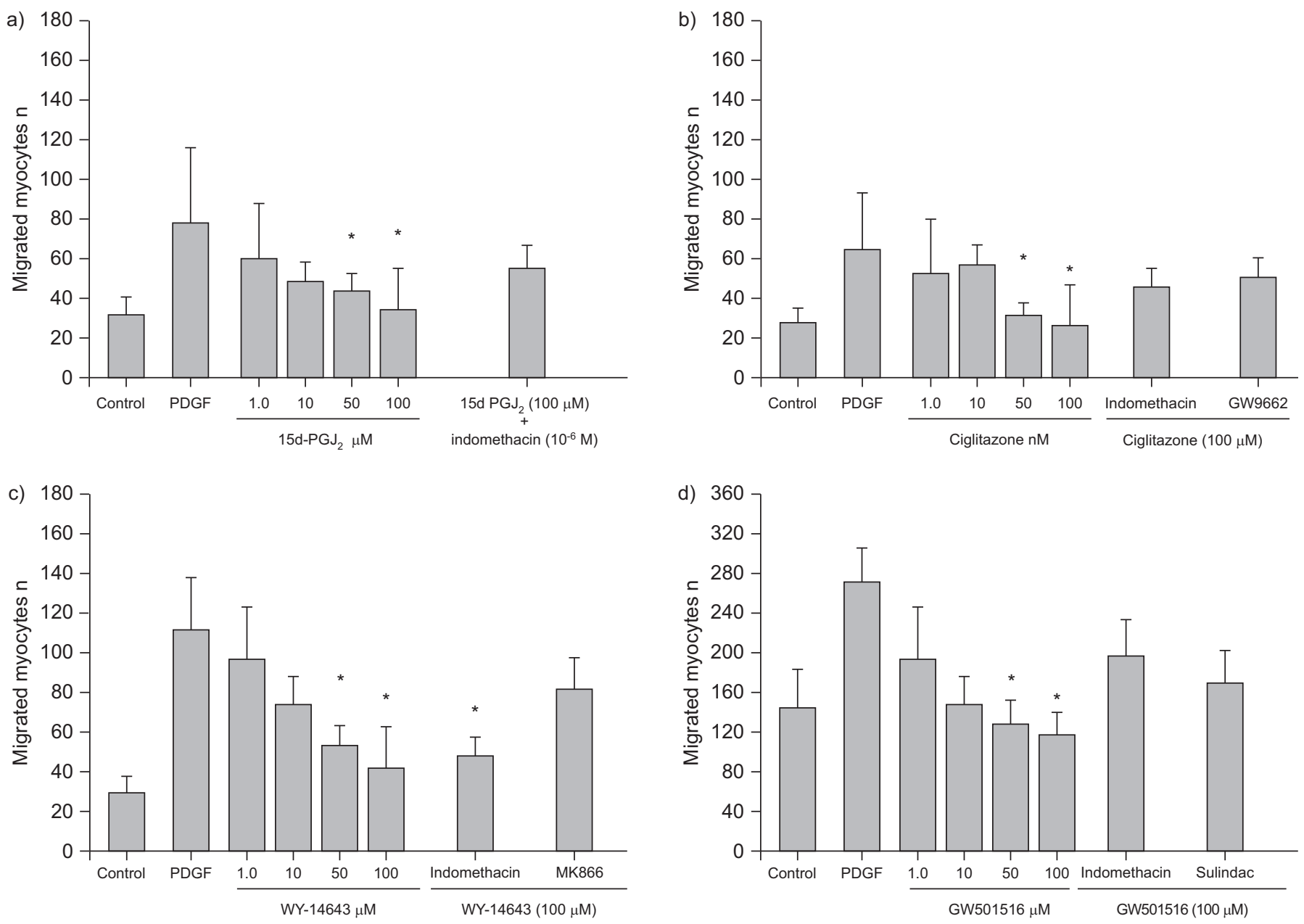

FIGURE 2. Migration of human airway smooth muscle cells towards platelet-derived growth factor (PDGF) was inhibited by peroxisome proliferator-activated receptor (PPAR) agonists. This inhibitory effect was abolished by $a, b, d$ ) indomethacin (for PPAR $\gamma$ and $\beta$ agonists) and specific PPAR isoform antagonists: d) GW9662 for PPAR $\gamma$, c) MK866 for PPAR $\alpha$ and d) sulindac for the PPAR . Data are presented as the mean \pm SD of a-c) five or d) four experiments. 15d-PG $J_{2}: 15-d e o x y-\Delta 12,14-$ prostaglandin $J_{2}$. *: $p<0.05$ compared with PDGF.

Danvers, MA, USA), or COX-1 and $-2(1: 2,000)$ (Millipore, Billerica, MA, USA) in 5\% BSA in TBS-T overnight followed by secondary anti-rabbit antibody (1:2,000) (anti-goat, 1:2,000 for COX-2) in 5\% milk-TBS-T for $1 \mathrm{~h}$. Membranes were washed extensively and proteins were detected with a standard chemiluminescence kit (Amersham Canada, Oakville, ON, Canada). The blots were then stripped in a low-pH glycine solution and re-probed with total Src $(1: 1,000)$ or total Akt $(1: 1,000)$ antibodies (BioSource International, Camarillo, CA, USA). PPAR isoforms on untreated HASM cells were detected by using anti-mouse polyclonal antibodies (1:1,000) (R\&D Systems) and sheep anti-mouse secondary antibody $(1: 2,000)$.

\section{Phosphatase assay}

PTEN activation was also assessed by a phosphatase assay. PTEN was immunoprecipitated from $500 \mu \mathrm{g}$ protein lysate using $1 \mu \mathrm{g}$ mouse anti-PTEN (Cell Signaling Technology), protein $\mathrm{G}$ agarose (Invitrogen) in immunoprecipitation buffer (50 mM Tris, pH 7.5; 100 mM NaCl; 15 mM EGTA; 0.1\% Triton $\mathrm{X}-100)$. The beads were rocked overnight at $4^{\circ} \mathrm{C}$, washed with $100 \mathrm{mM}$ Tris ( $\mathrm{pH}$ 8.0), resuspended in phosphatase buffer
(100 mM Tris, pH 8.0; $10 \mathrm{mM}$ dithiothreitol) in 96-well plates, and incubated with $5 \mu \mathrm{L}$ diC8-phosphatidylinositol-3,4,5-trisphosphate (Echelon Biosciences Inc., Salt Lake City, UT, USA), $15 \mu \mathrm{L}$ phosphatase buffer and $100 \mu \mathrm{L}$ Biomol Green (Biomol International, Plymouth Meeting, PA, USA). The free phosphate was measured at $630 \mathrm{~nm}$.

\section{Statistical analysis}

Statistical analysis was performed by ANOVA using the different time points or experimental conditions as withinsubject factors. The source of significant variation was identified by predefined contrasts. $p<0.05$ was considered significant. All analyses were performed using SPSS version 13.0 (Statistical Package for Social Sciences, Chicago, IL, USA).

\section{RESULTS}

\section{PPAR expression and activation}

HASM cells express PPAR $\alpha, \beta$ and $\gamma$ mRNA (fig. 1a) and protein (fig. 1b). A six-fold induction of luciferase activity was observed by stimulating cells with a pan-agonist, indicating endogenous PPAR activity (fig. 1c). This was attenuated by specific inhibitors of the three isoforms (fig. 1d). 
Fibronectin
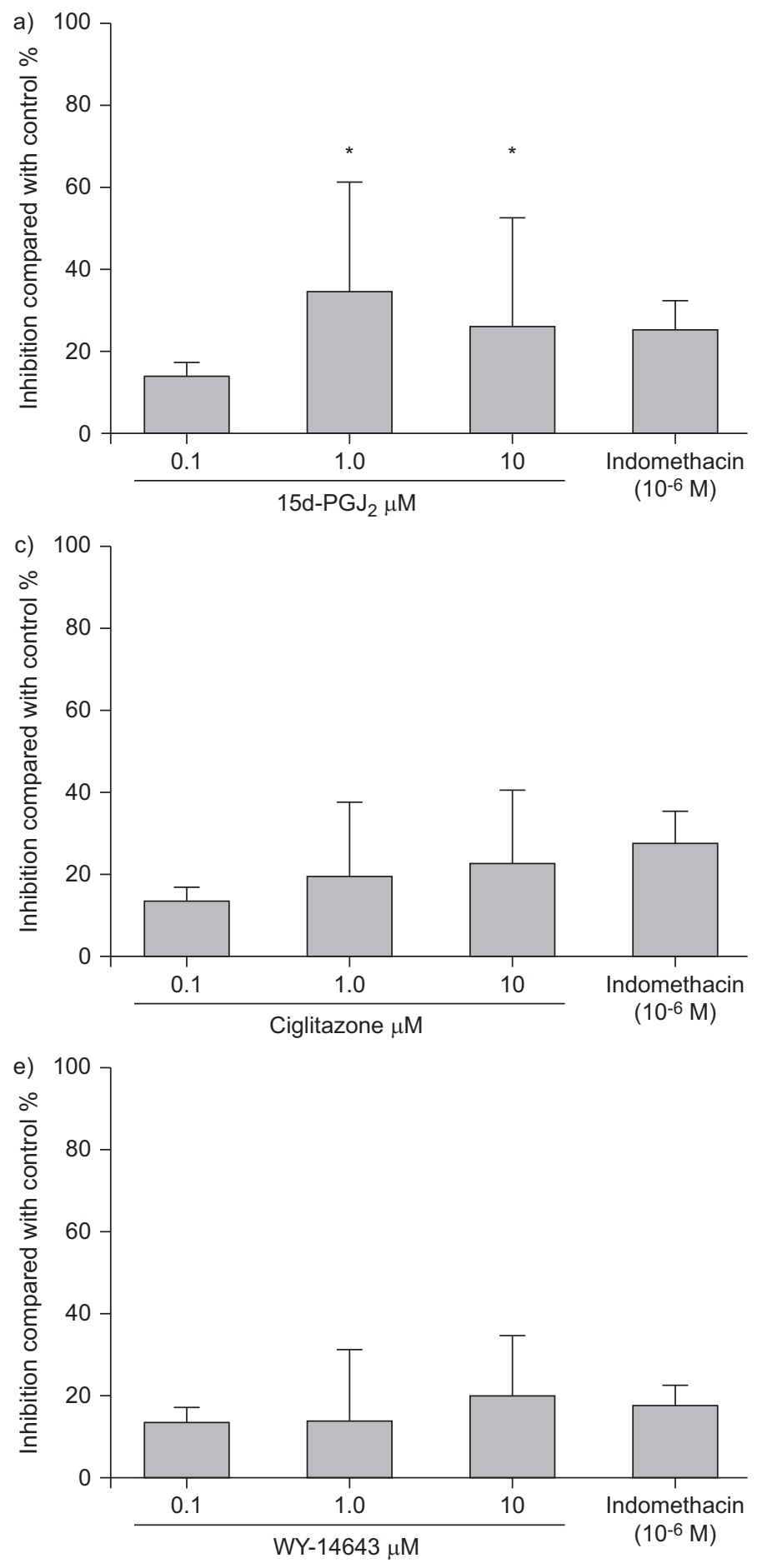

Collagen

b)

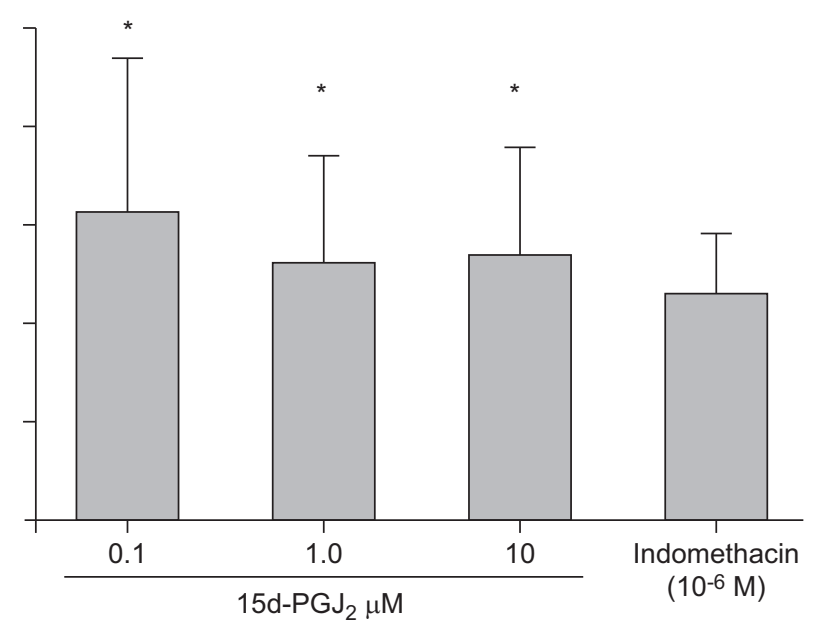

d)

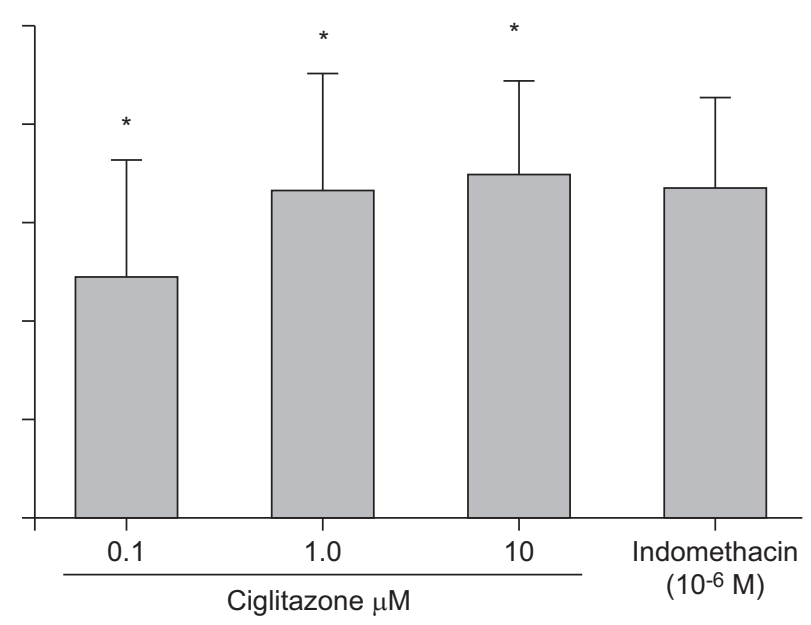

f)

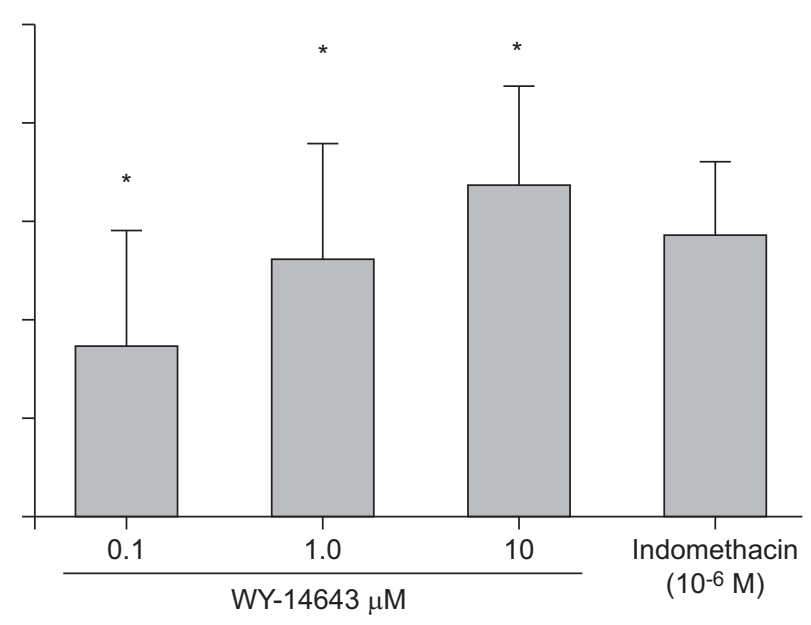

FIGURE 3. a, c, e) Fibronectin and b, d, f) collagen synthesis by human airway smooth muscle cells were inhibited by the peroxisome proliferator-activated receptor agonists a, b) 15-deoxy- $\Delta 12,14$-prostaglandin $J_{2}\left(15 d-P G J_{2}\right), c$, d) ciglitazone and e, f) WY-14643. This was unaffected by indomethacin. Data are presented as the mean \pm SD of four independent experiments. *: $p<0.05$ compared with control.

\section{Migration}

All four PPAR ligands, ciglitazone, 15d-PGJ 2 , WY-14643 and GW501516, decreased migration towards PDGF (fig. 2). The specificity of the isoforms is suggested by the ability of the specific PPAR antagonists to reverse the inhibitory effects.

\section{Matrix production}

All three PPAR ligands that we tested (ciglitazone, $15 \mathrm{~d}-\mathrm{PGJ}_{2}$ and WY-14643) inhibited collagen and fibronectin production by cultured smooth muscle cells (fig. 3). The effect on fibronectin was statistically significant only with $15 \mathrm{~d}-\mathrm{PGJ}_{2}$. The effect on 
a)

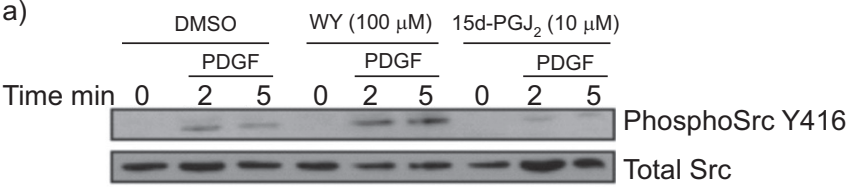

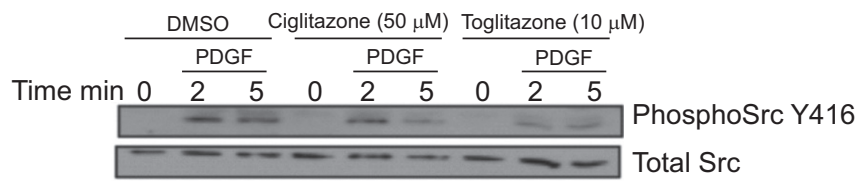

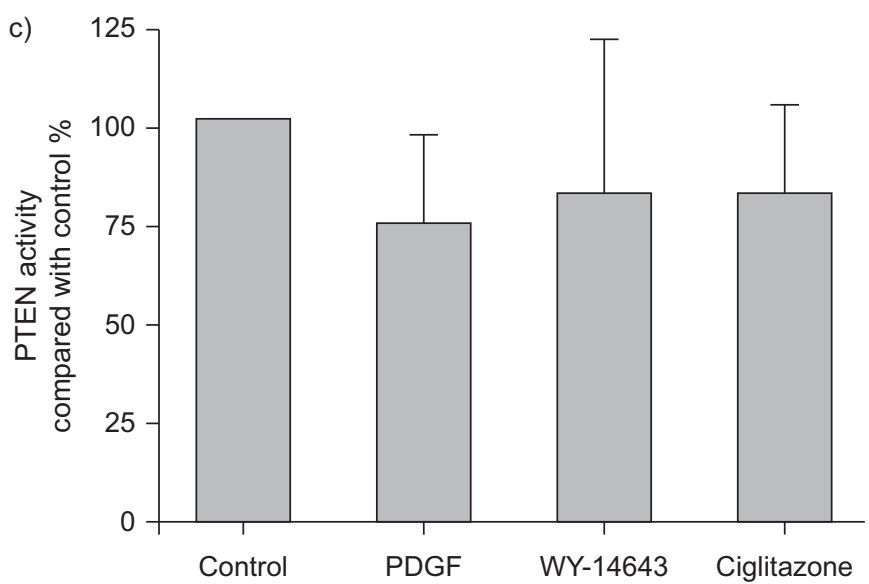

b)

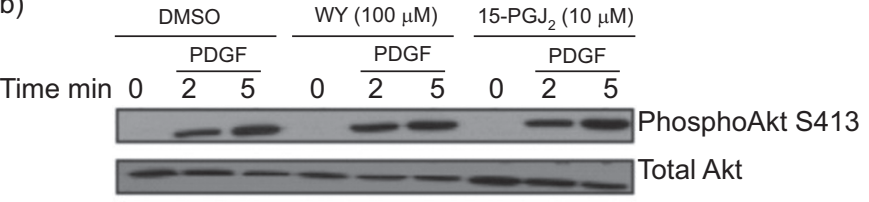

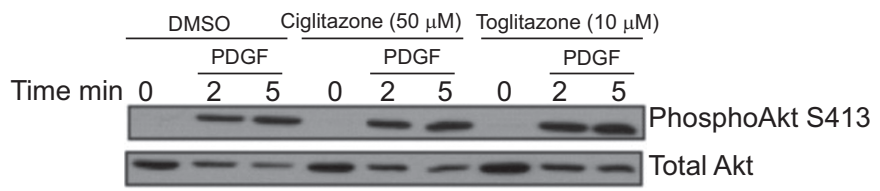

FIGURE 4. a) Total and phosphorylated Src were examined on cultured human airway smooth muscle (HASM) cells at 2 and 5 min after treating with platelet-derived growth factor (PDGF) in the presence of dimethylsulfoxide (DMSO) control, $100 \mu \mathrm{M} \mathrm{WY}$-14643, $10 \mu \mathrm{M}$ 15-deoxy- $\Delta 12,14$-prostaglandin $\mathrm{J}_{2}(15 \mathrm{~d}$-PGJ2), $50 \mu \mathrm{M}$ ciglitazone and $10 \mu \mathrm{M}$ troglitazone. The representative Western blot shows that peroxisome proliferator-activated receptor (PPAR) agonists, except $15 \mathrm{~d}-\mathrm{PG} \mathrm{J}_{2}$, do not increase total or phosphorylated Src on HASM cells. b) Total and phosphorylated Akt were examined on cultured HASM cells at 2 and 5 min after treating with PDGF in the presence of DMSO control, $100 \mu \mathrm{M} \mathrm{WY}-14643,10 \mu \mathrm{M} 15 \mathrm{~d}-\mathrm{PGJ}_{2}, 50 \mu \mathrm{M}$ ciglitazone and $10 \mu \mathrm{M}$ troglitazone. A representative western blot showing that PPAR agonists do not increase total or phosphorylated Akt kinase on human airway smooth muscle cells. c) PTEN (phosphatase and tensin homologue) activity was assayed using a phosphatase assay and the results were normalised for the control. There was no statistically significant difference in PTEN activity between PDGF $\left(10 \mathrm{ng} \cdot \mathrm{mL}^{-1}\right), \mathrm{WY}-14643(100 \mu \mathrm{M})$ and ciglitazone $(50 \mu \mathrm{M})$. Data are presented as the mean \pm SD of three independent experiments.

collagen was significant for all three concentrations of all the three agonists.

\section{Signalling}

PPAR ligands, except for $15 \mathrm{~d}_{-} \mathrm{PGJ}_{2}$, did not inhibit PDGFinduced increase in Akt or Src phosphorylation (fig. 4a and b) or increase PTEN activity (fig. 4c) in HASM cells. 15d-PGJ 2 attenuated Src phosphorylation (fig. 4a). In the presence of indomethacin, the inhibitory effects of $15 \mathrm{~d}-\mathrm{PGJ}_{2}$, ciglitazone and GW501516 on smooth muscle migration towards PDGF were attenuated. This was not observed on the inhibitory effect of WY-14643 (fig. 2). We also observed that $15 \mathrm{~d}-\mathrm{PGJ}_{2}$ and ciglitazone increased $\mathrm{PGE}_{2}$ (fig. 5a) and cAMP levels (data not shown) (1.6- and 1.2-fold, respectively) in cultured smooth muscle supernatant. Consistent with this, we observed activation of COX-2, but not COX-1, at 4 and $24 \mathrm{~h}$ after stimulation with 15d-PGJ 2 and ciglitazone (fig. 5b). WY-14643 did not increase $\mathrm{PGE}_{2}$ levels or induce COX-1 or COX-2 (data not shown).

\section{DISCUSSION}

We confirm previous observations of PPAR expression on HASM cells and we report three novel observations. First,
PPAR agonists decrease airway smooth muscle chemotaxis towards PDGF. Secondly, PPAR agonists also decrease collagen and fibronectin secretion by airway smooth muscle cells. Thirdly, the inhibition of migration seems to be mediated partly through the secretion of $\mathrm{PGE}_{2}$ and an increase in intracellular cAMP. These results suggest that PPAR agonists may be able to reverse some of the structural changes seen in the airway submucosa of patients with chronic severe asthma.

We confirm previous observations that HASM cells express the PPAR $\alpha$ and $\gamma$ isoforms [9-11]. In addition, they also express the PPAR $\beta$. We have confirmed this by demonstrating the presence of both the mRNA and protein. It is not clear why previous experiments using cultured smooth muscle cells did not demonstrate the expression of the PPAR $\beta / \delta$ isoforms. It may be related to the polyclonal nature of the antibody used (Santa Cruz Biotechnology, Santa Cruz, CA, USA) or the loss of expression with advanced passage of the cells (two to five passages in our experiments versus more than six passages in previous experiments). PPARs are endogenously active, as indicated by the PPRE-luciferase reporter assay. They are known to have potent anti-inflammatory effects on HASM cells. Here we report two additional biologically relevant 


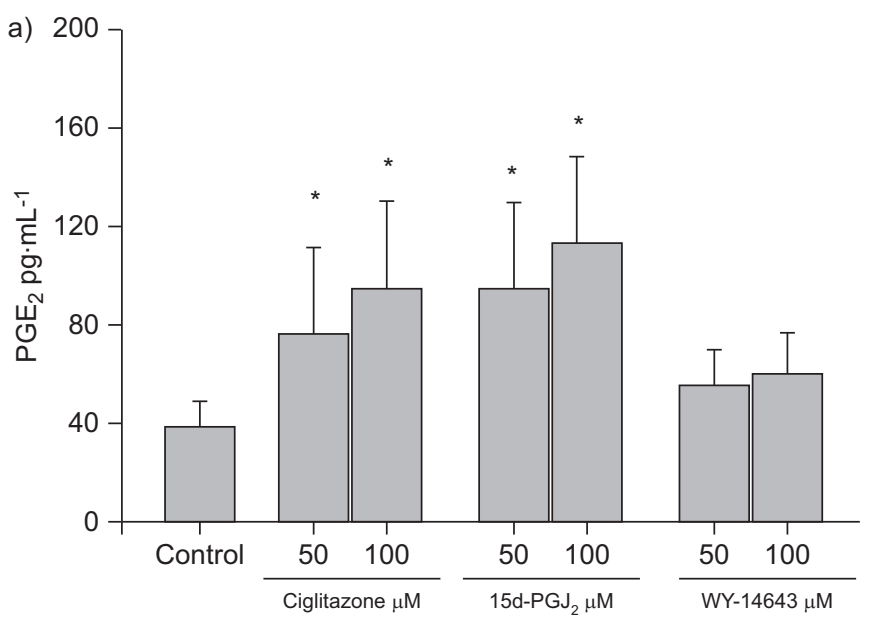

b)
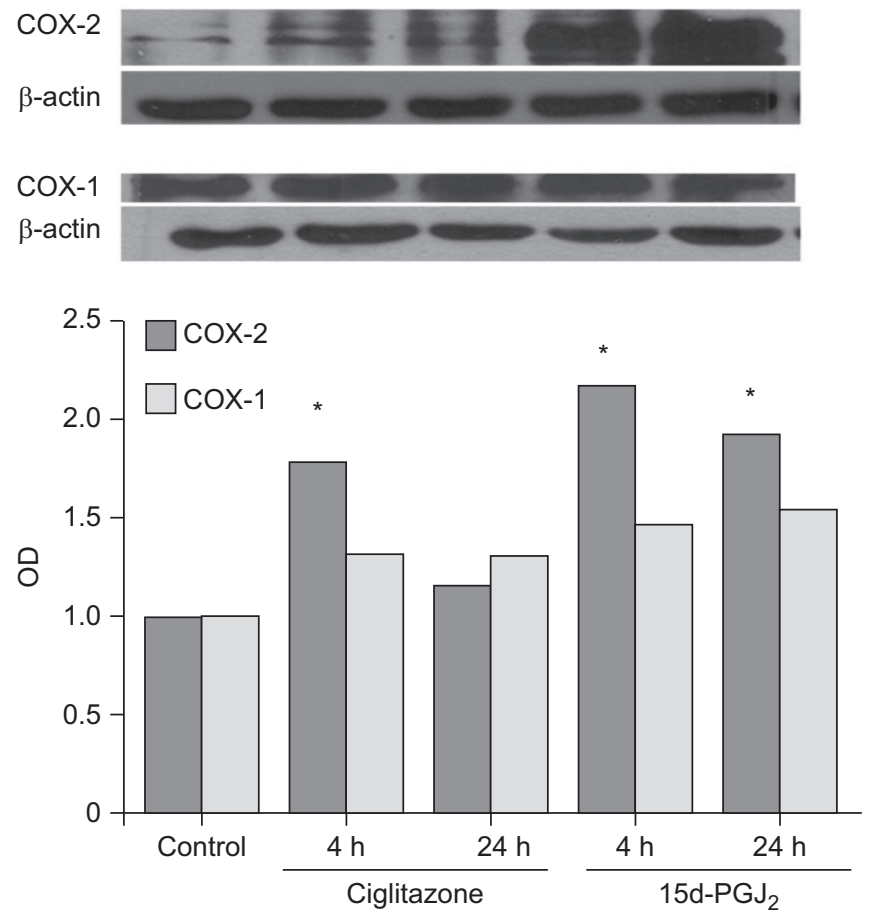

FIGURE 5. a) The peroxisome proliferator-activated receptor (PPAR) agonists ciglitazone and 15-deoxy- $\Delta 12,14$-prostaglandin $J_{2}$ (15d-PGJ2), but not WY-14643, increased prostaglandin $(P G) E_{2}$ synthesis (measured by enzyme immunosorbent assay) by human airway smooth muscle cells. b) The PPAR agonists ciglitazone and $15 \mathrm{~d}-\mathrm{PG} \mathrm{J}_{2}$ induced cyclooxygenase (COX)-2, but not COX-1, expression at 4 and $24 \mathrm{~h}$ after stimulation. Data are presented as the mean $\pm \mathrm{SD}$ of a) three or b) six independent experiments. OD: optical density. ${ }^{*}$ : $p<0.05$ compared with control.

effects of the molecule. Similarly to the observations in vascular tissue [12], we demonstrate that PPAR ligands are able to decrease airway myocyte migration towards PDGF. We examined relevant signalling mechanisms to understand this phenomenon. We did not observe inhibition of Src (except for with 15d-PGJ ${ }_{2}$ ) or PI3K activity or an increase in PTEN activity as potential mechanisms. However, we did observe that the inhibitory effect was attenuated by indomethacin. PPAR $\gamma$ agonists also caused an increase in $\mathrm{PGE}_{2}$ release from HASM cells and an induction of COX-2, and this is consistent with reports of COX induction by PPAR $\gamma$ agonists [16]. Thus, the decrease in muscle migration by PPAR $\gamma$ is most probably due to an increase in intracellular cAMP facilitated by $\mathrm{PGE}_{2}$. This is consistent with observations with other agents, such as $\beta$ agonists, that increase intracellular cAMP and decrease airway [21] and vascular [22] smooth muscle cell and fibroblast migration [23]. It is likely that cAMP modulates the morphology of smooth muscle cells by inhibiting a Rac-dependent signalling pathway resulting in disassembly of actin stress fibres and lamellipodia, loss of focal adhesions and the formation of small F-actin rings [24], thus decreasing the ability of cells to migrate. It is likely that PPAR $\beta$ also exerts its inhibitory effect through the same pathway as the effect was inhibited by indomethacin. We are unable to explain the mechanism of inhibitory effect of the PPAR $\alpha$ agonist. This is unlikely to be due to the same pathway as we did not observe either COX induction or an increase in $\mathrm{PGE}_{2}$ levels. This requires further investigation.

Although a PPRE has not been found upstream of ECM genes, there is evidence suggesting that PPAR may participate in the regulation of ECM genes, especially that of type I collagen [25, 26]. We observed a small, but statistically significant, decrease in collagen and fibronectin secretion from HASM cells. The precise mechanism needs further investigation. Unlike the effect on muscle migration, this does not appear to depend on intracellular cAMP levels as the observed phenomenon was not susceptible to inhibition by indomethacin. PPAR $\gamma$ agonists are reported to decrease TGF- $\beta$ expression in mesangial cells [13] and, since TGF- $\beta$ increases fibronectin and collagen secretion from airway smooth muscle cells [27], it is likely that PPAR ligands may decrease TGF- $\beta$ secretion by HASM cells. This needs further exploration.

These observations are likely to have important clinical relevance. Assuming that the chronic structural changes are detrimental to asthma pathophysiology [28], treatment with thiazolidinediones are likely to limit or even potentially reverse the two components of the remodelling processes that are currently not amenable to pharmacological therapy. This needs further evaluation in a clinical trial. In conclusion, PPAR ligands decrease HASM cell migration and matrix production, and are therefore potentially useful for modulating airway remodelling.

\section{SUPPORT STATEMENT}

This study was supported by a Firestone Institute-GlaxoSmithKline Research Award and an Ontario Thoracic Society Block-Term Grant. P. Nair holds a Canada Research Chair in Airway Inflammometry.

\section{STATEMENT OF INTEREST}

A statement of interest for the study itself can be found at www.erj. ersjournals.com/site/misc/statements.xhtml

\section{ACKNOWLEDGEMENTS}

We are grateful to the Dept of Pathology and the Division of Thoracic Surgery of St Joseph's Healthcare (Hamilton, ON, Canada) for their cooperation in obtaining lung specimens. 


\section{REFERENCES}

1 Jourbert P, Hamid Q. Role of airway smooth muscle in airway remodeling. J Allergy Clin Immunol 2005; 116: 713-716.

2 Ebina M, Takahashi T, Chiba T, et al. Cellular hypertrophy and hyperplasia of airway smooth muscles underlying bronchial asthma. A 3-D morphometric study. Am Rev Respir Dis 1993; 148: 720-726.

3 Woodruff PG, Dolganov GM, Ferrando RE, et al. Hyperplasia of smooth muscle in mild to moderate asthma without changes in cell size or gene expression. Am J Respir Crit Care Med 2004; 169: 1001-1006.

4 Parameswaran K, Cox G, Radford K, et al. Cysteinyl leukotrienes promote human airway smooth muscle migration. Am J Respir Crit Care Med 2002; 166: 738-742.

5 Kanabar V, Simcock DE, Mahn K, et al. Airway smooth muscle cell migration is increased in asthmatics. Proc Am Thorac Soc 2006; 3: A280.

6 Parameswaran K, Radford K, Zuo J, et al. Extracellular matrix regulates human airway smooth muscle cell migration. Eur Respir J 2004; 24: 545-551.

7 Pepe C, Foley S, Shannon J, et al. Differences in airway remodeling between subjects with severe and moderate asthma. J Allergy Clin Immunol 2005; 116: 544-549.

8 Moraes LA, Piqueras L, Bishop-Bailey D. Peroxisome proliferatoractivated receptors and inflammation. Pharmacol Ther 2006; 110: 371-385.

9 Benayoun L, Letuve S, Druilhe A, et al. Regulation of peroxisome proliferator-activated receptor gamma expression in human asthmatic airways: relationship with proliferation, apoptosis, and airway remodeling. Am J Respir Crit Care Med 2001; 164: 1487-1494.

10 Ward JE, Gould H, Harris T, et al. PPAR gamma ligands, 15-deoxy$\Delta 12,14$-prostaglandin $\mathrm{J}_{2}$ and rosiglitazone regulate human cultured airway smooth muscle proliferation through different mechanisms. Br J Pharmacol 2004; 141: 517-525.

11 Patel HJ, Belvisi MG, Bishop-Bailey D, et al. Activation of peroxisome proliferator-activated receptors in human airway smooth muscle cells has a superior anti-inflammatory profile to corticosteroids: relevance for chronic obstructive pulmonary disease therapy. J Immunol 2003; 170: 2663-2669.

12 Marx N, Schonbeck U, Lazar MA, et al. Peroxisome proliferatoractivated receptor gamma activators inhibit gene expression and migration in human vascular smooth muscle cells. Circ Res 1998; 83: 1097-1103.

13 Zheng F, Fornoni A, Elliot SJ, et al. Upregulation of type I collagen by TGF- $\beta$ in mesangial cells is blocked by PPAR $\gamma$ activation. Am J Physiol Renal Physiol 2002; 282: F639-F648.

14 Belvisi MG, Hele DJ. Peroxisome proliferators activated receptors as novel targets in lung disease. Chest 2008; 134; 152-157.
15 Straus DS, Glass CK. Anti-inflammatory actions of PPAR ligands: new insights on cellular and molecular mechanisms. Trends Immunol 2007; 28: 551-558.

16 Pang L, Nie M, Corbett L, et al. Cyclooxygenase-2 expression by nonsteroidal anti-inflammatory drugs in human airway smooth muscle cells: role of peroxisome proliferator-activated receptors. J Immunol 2003; 170: 1043-1051.

17 Kawai T, Masaki T, Doi S, et al. PPAR- $\gamma$ agonist attenuates renal interstitial fibrosis and inflammation through reduction of TGF- $\beta$. Lab Invest 2009; 89: 47-58.

18 Poleni PE, Etienne $S$, Velot E, et al. Activation of PPARs $\alpha, \beta / \delta$, and $\gamma$ impairs TGF- $\beta 1$-induced collagens' production and modulates the TIMP-1/MMPs balance in three-dimensional cultured chondrocytes. PPAR Res 2010; 2010: 635912.

19 Delvecchio CJ, Bilan $\mathrm{P}$, Radford $\mathrm{K}$, et al. Liver $\mathrm{X}$ receptor stimulates cholesterol efflux and inhibits expression of proinflammatory mediators in human airway smooth muscle cells. Mol Endocrinol 2007; 21: 1324-1334.

20 Delvecchio CJ, Bilan $\mathrm{P}$, Nair $\mathrm{P}$, et al. LXR-induced reverse cholesterol transport in human airway smooth muscle is mediated exclusively by ABCA1. Am J Physiol Lung Cell Mol Physiol 2008; 295: L949-L957.

21 Goncharova EA, Billington CK, Irani C, et al. Cyclic AMPmobilizing agents and glucocorticoids modulate human smooth muscle cell migration. Am J Respir Cell Mol Biol 2003; 29: 19-27.

22 Newman WH, Castresana MR, Webb JG, et al. Cyclic AMP inhibits production of interleukin-6 and migration in human vascular smooth muscle cells. J Surg Res 2003; 109: 57-61.

23 Rieder F, Georgieva M, Schirbel A, et al. Prostaglandin $E_{2}$ inhibits migration of colonic lamina propria fibroblasts. Inflamm Bowel Dis 2010; 16: 1505-1513.

24 Pelletier S, Julien C, Popoff MR, et al. Cyclic AMP induces morphological changes of vascular smooth muscle cells by inhibiting a Rac-dependent signaling pathway. I Cell Physiol 2005; 204: 412-422.

25 Isshiki K, Haneda M, Koya D, et al. Thiazolidinedione compounds ameliorate glomerular dysfunction independent of their insulinsensitizing action in diabetic rats. Diabetes 2000; 49: 1022-1032.

26 McGowan SE, Jackson SK, Doro MM, et al. Peroxisome proliferators alter lipid acquisition and elastin gene expression in neonatal rat lung fibroblasts. Am J Physiol Lung Cell Mol Physiol 1997; 273: L1249-L1257.

27 Moir LM, Burgess JK, Black JL. Transforming growth factor $\beta 1$ increases fibronectin deposition through integrin receptor $\alpha 5 \beta 1$ on human airway smooth muscle. J Allergy Clin Immunol 2008; 121: 1034-1039.

28 McParland BE, Macklem PT, Pare PD. Airway wall remodeling: friend or foe? J Appl Physiol 2003; 95: 426-434. 